\title{
Chagas disease in the State of Amazonas: history, epidemiological evolution, risks of endemicity and future perspectives
}

\author{
Maria das Graças Vale Barbosa[1],[2],[5], João Marcos Bemfica Barbosa Ferreira[1], [3], \\ Ana Ruth Lima Arcanjo ${ }^{[4]}$, Rosa Amélia Gonçalves Santana ${ }^{[1]}$, Laylah Kelre Costa \\ Magalhães ${ }^{[1]}$, Laise Kelma Costa Magalhães ${ }^{[1]}$, Daniel Testa Mota ${ }^{[5]}$, Nelson Ferreira Fé[2], \\ Wuelton Marcelo Monteiro[1],[2], Henrique Silveira ${ }^{[6]}$ and Jorge Augusto de Oliveira Guerra ${ }^{[1],[2]}$
}

[1]. Programa de Pós-Graduação em Medicina Tropical, Escola de Ciências da Saúde, Universidade do Estado do Amazonas, Manaus, AM. [2]. Fundação de Medicina Tropical Dr. Heitor Vieira Dourado, Manaus, AM. [3]. Hospital Francisca Mendes, Manaus, AM. [4]. Fundação de Vigilância em Saúde, Manaus, AM. [5]. Programa de Pós Graduação em Biologia Urbana, Universidade Nilton Lins, Manaus, AM. [6]. Instituto de Higiene e Medicina Tropical, Universidade Nova de Lisboa, Lisboa, Portugal.

\begin{abstract}
Chagas disease (CD) is a parasitic infection that originated in the Americas and is caused by Trypanosoma cruzi. In the last few years, the disease has spread to countries in North America, Asia and Europe due to the migration of Latin Americans. In the Brazilian Amazon, CD has an endemic transmission, especially in the Rio Negro region, where an occupational hazard was described for piaçaveiros (piassaba gatherers). In the State of Amazonas, the first chagasic infection was reported in 1977, and the first acute CD case was recorded in 1980. After initiatives to integrate acute CD diagnostics with the malaria laboratories network, reports of acute $\mathrm{CD}$ cases have increased. Most of these cases are associated with oral transmission by the consumption of contaminated food. Chronic cases have also been diagnosed, mostly in the indeterminate form. These cases were detected by serological surveys in cardiologic outpatient clinics and during blood donor screening. Considering that the control mechanisms adopted in Brazil's classic transmission areas are not fully applicable in the Amazon, it is important to understand the disease behavior in this region, both in the acute and chronic cases. Therefore, the pursuit of control measures for the Amazon region should be a priority given that $\mathrm{CD}$ represents a challenge to preserving the way of life of the Amazon's inhabitants.
\end{abstract}

Keywords: Chagas' disease. Brazilian Amazon. State of Amazonas. Trypanosoma cruzi.

\section{INTRODUCTION}

Chagas disease (CD) is a parasitic infection caused by Trypanosoma cruzi that was discovered more than 100 years ago by the Brazilian researcher Carlos Chagas ${ }^{(1)}$. CD has a wide distribution in the Americas and has spread to various countries including Canada, the United States, Spain, Japan and Australia due to migration by Latin Americans in recent years ${ }^{(2)(3)(4)}$.

The transmission of T. cruzi occurs mainly through vectors, blood transfusions, vertical transmission and oral transmission, the latter being the main transmission form reported in the acute outbreaks that have been occurring in the Amazon ${ }^{(5)(6)(7)}$. CD is characterized by an acute phase, most often asymptomatic, that can develop into an indeterminate asymptomatic chronic phase or to the cardiac or digestive chronic forms ${ }^{(6)(7)}$.

Corresponding author: Profa. Maria das Graças Vale Barbosa. FMTHVD. Av. Pedro Teixeira 25, Dom Pedro, 69040-000 Manaus, AM, Brasil.

Phone: 5592 2127-3516

e-mail: gbarbosa@fmt.am.gov.br

Received 10 December 2013

Accepted 11 September 2014
In Brazil, the CD epidemiological situation was substantially altered as a result of the vector control measures taken, as well as environmental, economic and social changes ${ }^{(6)(8)}$. The current control measures include epidemiological surveillance and the control of the blood banks, together with attempts to meet the challenge of providing medical care and social security benefits to approximately three million infected people in whom the chronic form of the disease predominates ${ }^{(6)(8)(9)}$.

In the late 1970s, 18 Brazilian states were included in the $\mathrm{CD}$ endemic areas with risk of disease transmission by the main vector Triatoma infestans ${ }^{(10)}$. After 1975, systematic chemical control measures were adopted and maintained, leading to a significant reduction of this vector and a simultaneous reduction in the transmission of T. cruzi to humans ${ }^{(6)(10)(11)}$. The Serologic National Inquiry performed from 1975 to $1980^{(12)}$ indicated a prevalence of $4.22 \%$ for the entire country; the average prevalence for the northern region states alone was $0.92 \%$. The municipalities of Barcelos and Novo Airão in the Rio Negro region of the State of Amazonas showed infection rates higher than the national average. The results of the Serologic National Inquiry for Chagas infection in Brazil (1975/1980) and the entomological survey, held almost simultaneously, decisively 
supported the implementation of activities controlling Chagas disease in the country ${ }^{(8)}$.

A high prevalence of Chagas disease in urban centers and a lack of control programs in the 1970s resulted in the transmission of 20,000 new cases annually in Brazil via the transfusion of T. cruzi. During the 1980s and 1990s, blood transfusion was the main mechanism of the dissemination of $\mathrm{CD}$ in endemic areas. Improved screening of blood donors substantially reduced the rate of blood-borne transmission ${ }^{(11)}$.

In 2006, in recognition of the progress achieved, Brazil received an international certification issued by the Pan American Health Organization and the World Health Organization for the interruption of CD transmission by T. infestans ${ }^{(13)}$.

In 2011, the results of a seroprevalence survey on CD conducted among children indicated the virtual absence of $\mathrm{CD}$ transmission through vectors in Brazil ${ }^{(9)}$. From 2000 to 2011, 1,252 acute CD cases were reported in Brazil. Of these, $877(70 \%)$ occurred by oral transmission, and $92(7 \%)$ occurred by vector transmission. In $276(22 \%)$ cases, the transmission form was not identified ${ }^{(14)}$.

Between 1999 and 2007, there were 53,930 deaths for which Chagas disease was mentioned in any way on the death certificate. Fifty-five $(3,050)$ percent of 5,565 municipalities reported at least one death related to Chagas disease in this period. The mean mortality in Brazil was 3.37/100,000 inhabitants/year, ranging from 0.0 to 138.06 deaths per 100,000 inhabitants ${ }^{(15)}$.

According Coura et al. ${ }^{(6)}$, the control and surveillance initiatives relating to Chagas disease have created new expectations among the Latin American community and in non-endemic countries that have received migrants from our continent regarding the possibility of worldwide control over Chagas disease within the next 20 years. These possibilities can be realized, but only with constant, enduring control and perpetual surveillance.

\section{CHAGAS DISEASE IN THE BRAZILIAN AMAZON}

In the Brazilian Amazon, the low CD prevalence and morbimortality rates, along with the notion that $T$. cruzi transmission to humans requires domestic vectors, generated a long-lasting consensus that the disease was not a public health problem in the region ${ }^{(5)}$. In the last few years, the identification of an increasing number of CD acute ${ }^{(5)(14)(16)}$ and chronic cases $^{(5)(9)(17)}$ reiterated that the disease was endemic in the entire Amazon region and that it exhibited particular sub-regional characteristics. In this region, a transmission cycle occurs with a wide array of vectors and wild reservoirs carrying the etiologic agent ${ }^{(6)(18)(19)(20)}$. According to the Brazilian Ministry of Health, there were more than 1,000 acute $\mathrm{CD}$ cases reported from 2005 to 2010 . Of these, $879(87 \%)$ occurred in the states that constitute the Legal Amazon, and the Brazilian states with the largest numbers of recorded cases were Pará, Amapá and Amazonas [Secretaria de Vigilância em Saúde (FVS), preliminary data] ${ }^{(14)}$.

Among the main risk factors associated with T. cruzi transmission in the Amazon are the following: a) the construction of houses in rural areas close to palm groves infested with triatomines and marsupials infected with $T$. cruzi; b) the extensive landscape transformation caused by deforestation and the proliferation of opportunistic mammals such as rodents and marsupials in degraded environments; c) the sporadic invasion of domiciles by wild adult vectors, mainly Rhodnius pictipes, Rhodnius robustus and Panstrongylus geniculatus; d) the introduction of electricity (being potentially involved in this transmission process); e) human migration from endemic areas into the Amazon with the possibility of unintentionally introducing alien parasitic strains and vectors; f) the extraction of piassaba fibers in middle and upper Rio Negro (Brazil, Colombia and Venezuela); and g) the consumption of contaminated fruit juices, such as açai berry and other palm fruit juices ${ }^{(5)(6)(8)(18)(20)(21)}$.

In the early 2000s, recognizing that Chagas disease was an endemic and public health problem in Amazonia, scientists from Latin America supported by the Pan American Health Organization sponsored international initiatives for the prevention of Chagas disease in Amazonia (Amazon Country Initiative-AMCHA). This provided a framework upon which to build the political, scientific, technological, and economic cooperation networks required to confront the challenge of preventing Chagas disease in Amazonia ${ }^{(18)(22)}$.

The aim of this article is to describe the current situation regarding Chagas disease in the State of Amazonas and to describe the role played over the years by health institutions in the generation of knowledge and human resources capable of controlling this endemic disease.

\section{CHAGAS DISEASE IN THE STATE OF AMAZONAS}

The first T. cruzi infection in the state of Amazonas was reported in 1977, and it consisted of six cases that were detected by serological methods, all of them in piassaba gatherers from the Barcelos municipaliy ${ }^{(23)}$. However, the first report of acute CD occurred in 1980 in São Paulo de Olivença ${ }^{(24)}$ while the first report of an acute case in the state capital, Manaus, occurred in 1994 in the city's urban area ${ }^{(25)}$. Since then, there have been increasingly frequent records of acute and chronic cases, mainly in the countryside (17) (26) (27) (28) (29) (30)(31) (32) (33) (34) (35) (36). The first xenodiagnosis performed in a chronic patient from the upper Rio Solimões region was made in 1999, from a colony of Triatoma maculata found inside the houses and chicken coops of the Macuxi Indians in the municipality of Normandia, State of Roraima ${ }^{(37)}$. Entomological surveys conducted in the municipalities of Coari, Manaus and Presidente Figueiredo demonstrated that the predominant vector species are $R$. pictipes, $R$. robustus and $P$. geniculatus. The infection rate by T. cruzi ranges from $30 \%$ to $50 \%$ among the various localities (Barbosa MVG, unpublished data).

Between 1980 and 2013, 111 acute CD cases were recorded in the State of Amazonas (Figure 1 and Figure 2) that were distributed over 19 of the 62 municipalities. The increase in the number of cases reflects diverse factors linked to more frequent human contact with populations of wild triatomines, enabling the occurrence of cases of DC, principally acute forms, which are isolated or linked to outbreaks by oral transmission; 


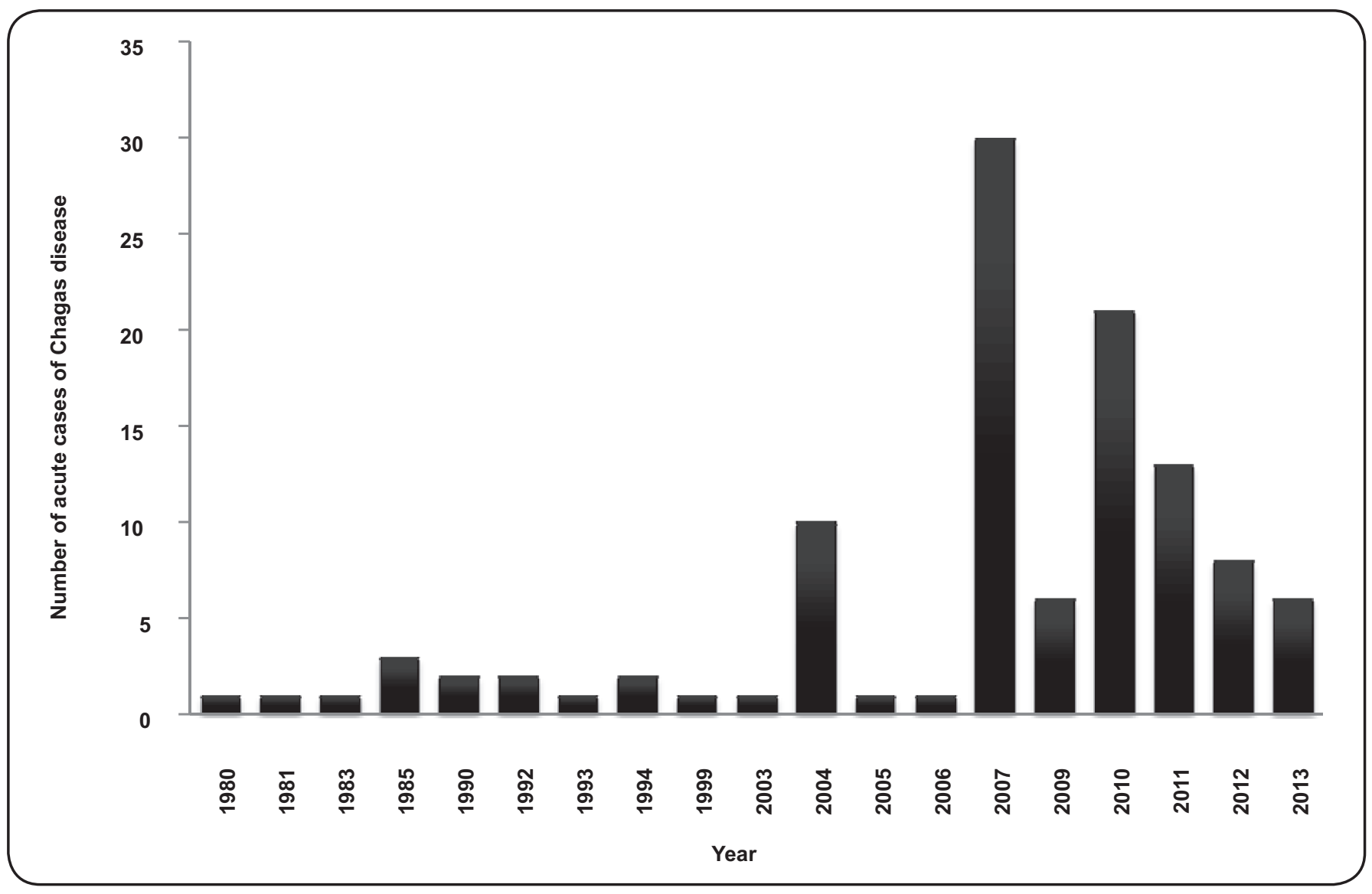

FIGURE 1 - Distribution of acute cases of Chagas disease in the State of Amazonas from 1980 to 2013.

this increase also reflects improvements in the diagnosis of cases and increased vigilance by malaria-targeted services. Of note is the training of malaria technicians, which was stimulated by the meetings and initiatives of $\mathrm{AMCHA}^{(22)}$.

Among the reported cases, four were outbreaks of acute cases, all of which were associated with oral transmission by açaí juice intake. The first outbreak occurred in Tefé in 2004 and consisted of nine cases $^{(32)}$ the second one occurred in Coari in 2007 and consisted of 26 cases $^{(33)(34)}$ the third one occurred in Santa Isabel do Rio Negro in $2010^{(36)}$ and consisted of 17 cases. In addition to the acute outbreaks, four isolated acute cases were recorded in Coari and Santa Isabel do Rio Negro, in 2007 and 2010, respectively (Figure 1); the most recent one occurred in Carauari in 2011 and consisted of 12 cases (unpublished data). In all the outbreaks, early detection by the network for the microscopic diagnosis of malaria, as well as the prompt service provided by the staff of the Tropical Medicine Foundation Doutor Heitor Vieira Dourado [Fundação de Medicina Tropical Dr. Heitor Vieira Dourado (FMT-HVD)] and the Foundation for Health Surveillance [Fundação de Vigilância em Saúde (FVS)], was fundamental in the adoption of control measures and the treatment of patients.

The occurrence of isolated cases in different municipalities of the state suggests vectorial transmission. The municipality of Manaus draws particular attention, having registered seven cases. Furthermore, the increase of cases in recent years coincides with the expansion of the city and greater human influx to rural areas. In these areas, alteration of the rainforest environment restricts food reservoirs for wildlife. The loss of their natural food sources has attracted triatominae to human houses in search of alternatives, resulting in increased contact with humans and increasing frequencies of acute and chronic cases. Human serological investigations aimed at recording indeterminate cases have been carried out in the outskirts of Manaus and in some rural settlements - i.e., in Coari, Tefe and Barcelos, respectively - and have encountered significant rates of infection ${ }^{(17)(38)(39)}$.

Chronic CD morbidity was lower in the State of Amazonas than in the classical endemic areas, with the disease occurring mainly in the indeterminate form ${ }^{(17)(38)(39)}$. In general, there were no differences in the proportion of radiological changes between positive and negative groups, suggesting low morbidity in the chronic phase of CD in the State of Amazonas, which was likely related to low parasitemia and/or reduced pathogenicity of the sylvatic $T$. cruzi strain in this region ${ }^{(31)}$.

Serological surveys and cross-sectional studies, including clinical and electrocardiographic evaluations, were conducted on seroreactive patients from urban and rural areas, especially from Manaus, Barcelos, Coari, Tefé and several riverside and 


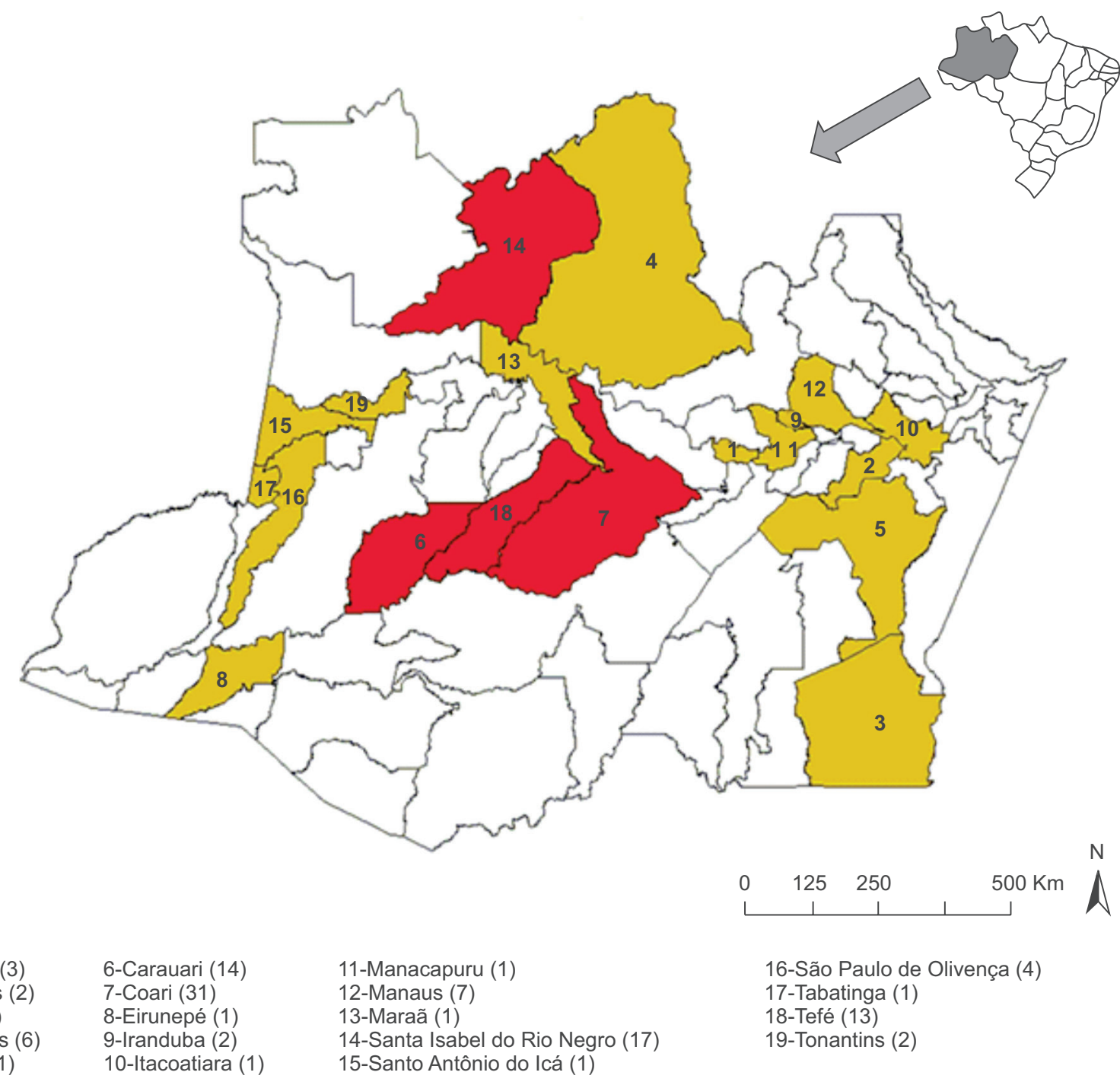

FIGURE 2 - Chagas disease distribution. Municipalities where Chagas disease outbreaks occurred are shown in red. Municipalities where isolated acute cases were reported are shown in orange.

piassaba-gathering populations from the Rio Negro and its tributaries. These studies showed that the prevalence of chagasic infection ranged from 1-13\%, with low morbidity in the chronic phase. In Amazonas, studies have reported a prevalence varying from 3.5 to $1.4 \%$, depending on the region ${ }^{(11)(39)(40)}$. Coura et al. ${ }^{(40)}$ reported prevalences in the urban area of Barcelos, State of Amazonas; upon encountering a markedly low prevalence, they recommended that studies conducted in Amazonia should use at least two tests [indirect immunofluorescence antibody test) (IFI) + enzyme-linked immunosorbent assay(ELISA)] and be verified by Western blot $^{(17)(27)(38)(40)}$.

A seroprevalence study with 1,263 samples from residents of Manaus, Coari and Tefé consisted of $15(1.2 \%)$ seroreactive individuals, 12 of whom were native to the State of Amazonas and had no family history of CD or cardiac alterations ${ }^{(17)}$. However, in the upper and middle Rio Negro, two cases of severe dilated cardiomyopathy with positive serology for chagasic infection, which resulted in death, were found ${ }^{(27)}$. Subsequently, new cases with reactive serology for T. cruzi were reported with clinical, electrocardiographic and echocardiographic characteristics suggestive of chronic chagasic cardiomyopathy, manifesting clinically as heart failure, arrhythmogenic syndrome and thromboembolism ${ }^{(28)(29)}$.

The advances made in understanding the molecular epidemiology of $\mathrm{CD}$ allowed the molecular classification of T. cruzi into six strains called discrete typing units (DTUs)

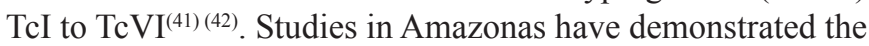
presence of DTUs TcI, TcIII and TcIV in the parasite sylvatic transmission cycle ${ }^{(33)(34)(35)(38)}$. TcIV predominates among orally transmitted acute human cases ${ }^{(34)}$, and TcI predominates among the isolated and chronic cases ${ }^{(35)(38)}$, suggesting their association with different transmission profiles. The T. cruzi isolates 
showed variable behavior in experimental infections in mice, promoting low parasitemia, virulence and pathogenicity, which is compatible with the low parasitemia and morbidity profile of $\mathrm{CD}$ in humans and with the poor performance of diagnostic methods in the region ${ }^{(43)}$. In mice, the frequency of resistance to benznidazole among the TcIV isolates was significantly higher than in the TcI isolates ${ }^{(35)}$. To date, TcII, TcV and TcVI, which are the predominant DTUs in humans and in domiciliary and peri-domiciliary vectors in the Southern Cone ${ }^{(41)(42)}$ of the continent, have not been reported in Amazonas.

\section{FINAL CONSIDERATIONS}

A large constellation of factors pertain to the disease in the Amazon region, including the following: oral transmission; isolated cases of vector transmission; areas of intense and continuous contact with wild vectors; and population surveys showing significant rates of infection at the periphery of large and medium-sized cities. With regard to these factors and the clinical profile that has been taking shape, as well as existing knowledge (which, although limited, is expanding in the Amazon and has been fundamental to the role of services already installed and/or programs already in operation that support the actions of epidemiological and environmental surveillance, following what was recommended at the Second Meeting of AMCHA $^{(22)}$; Technical Report 2006), accounting for morbidity and medical care for those individuals sick or infected by T. cruzi became a priority in terms of integration into other activities.

Given the need to properly recognize and treat positive cases at the FMT-HVD, different methodologies are used in routine diagnosis: 1) Trypanosoma cruzi culture, 2) xenodiagnosis and 3) polymerase chain reaction (PCR) mapping of T. cruzi isolated from humans, vectors and reservoirs.

Currently, a hierarchical medical system with referral and counter-referral between the basic healthcare units and reference centers for the treatment, diagnosis and control of $\mathrm{CD}$ has been implemented in Amazonas. Health professionals of all levels have been trained because professionals from small municipalities still often believe that the disease does not exist in the region, which contributes to the non-detection of the disease or its late diagnosis, especially in chronic cases.

Since its inception in 1974, the FMT-HVD has been the unit of referral and regional counter-referral for $\mathrm{CD}$ patient care. Other institutions are also involved in the care and diagnosis of $\mathrm{CD}$, such as the Amazon Foundation of Hematology and Hemotherapy [Fundação de Hematologia e Hemoterapia do Amazonas (FHEMOAM)], which is responsible for blood donor screening, the Foundation for Health Surveillance (FVS) and the Hospital Francisca Mendes (HFM) through its Department of Cardiology. The establishment of referral and counter-referral services of infectology, cardiology and blood banks has been extremely important in the detection of chronic cases, and the FMT-HVD has been involved in this process for a long time. Data from the FMT-HVD outpatient clinic allowed the detection of 26 new cases of chronic CD in 2012.

Considering that the $\mathrm{CD}$ control mechanisms adopted in the classic transmission areas in Brazil are not fully applicable in the Amazon region, knowledge about the disease behavior in this region, of both acute and chronic cases regardless of autochthony, is extremely important. The surveillance strategy for acute cases and the early diagnosis and treatment through the detection of cases by thick smears, the technique recommended for malaria diagnosis, form an opportune and efficient solution that is applicable to asymptomatic acute cases. Therefore, it is essential that every microscopist from public or private healthcare units is able to recognize T. cruzi.

Amazonas has been structuring its services to strengthen control efforts and meet unique needs in the management of outbreaks of acute cases to reduce lethality. In parallel, the FMT-HVD, in partnership with local and international academic institutions, has been promoting specific lines of research on CD within undergraduate research institutions, medical residencies, sensu lato specializations and master and doctorate programs.

The joint action of healthcare, academic and research institutions and epidemiological surveillance services is essential. Facing the situation together will allow a better approach to a disease whose exact magnitude is still unknown and that requires a high level of suspicion for its detection and timely treatment. Effective inter-sector actions within the education and environmental sectors are crucial for the implementation of health education measures that may reduce the risk of occupational or accidental exposure to T. cruzi and for the incorporation of the risk of acquiring $\mathrm{CD}$ among the priorities of the environmental agenda in the region.

\section{ACKNOWLEDGMENTS}

The authors thank all the staff of the Tropical Medicine Foundation Doutor Heitor Vieira Dourado and the Foundation for Health Surveillance of the State of Amazonas involved in monitoring the cases of $\mathrm{CD}$ and caring for the affected patients in Amazonas. The authors also thank Professor José Rodrigues Coura for the motivation in studying this subject.

\section{CONFLICT OF INTEREST}

The authors declare that there is no conflict of interest.

\section{FINANCIAL SUPPORT}

We would like to thank the financial support from Fundação Medicina Tropical Heitor Vieira Dourado, Manaus, Brazil, the National Council for Scientific and Technological Development (Conselho Nacional de Desenvolvimento Científico e Tecnológico - CNPq), and by the Department of Science and Technology of the Ministry of Health of Brazil (Departamento de Ciência e Tecnologia do Ministério da Saúde do Brasil - DECIT/ MS, number 410398/2006-3 (Edital Doenças Negligenciadas) and the Amazonas Research Foundation (Fundação de Amparo a Pesquisa do Estado do Amazonas-FAPEAM) (PPSUS grant call for proposals no. 007/2009). 


\section{REFERENCES}

1. Chagas C. Nova tripanozomiaze humana: estudos sobre a morfolojia e o ciclo evolutivo do Schizotrypanum cruzi n. gen., n. sp., ajente etiolojico de nova entidade morbida do homem. Mem Inst Oswaldo Cruz 1909; 1:159-218.

2. Bern C, Kjos S, Yabsley MJ, Montgomery SP. Trypanosoma cruzi and Chagas disease in the United States. Clin Microbiol Rev 2011; 24:655-681.

3. Murcia L, Carrilero B, Munoz-Davila MJ, Thomas MC, Lopez MC, Segovia M. Risk factors and primary prevention of congenital Chagas disease in a nonendemic country. Clin Infect Dis 2013; 56:496-502.

4. Schmunis G. Epidemiology of Chagas disease in non endemic countries: the role of international migration. Mem Inst Oswaldo Cruz 2007; 102:75-86.

5. Coura J, Junqueira A. Risks of endemicity, morbidity and perspectives regarding the control of Chagas disease in the Amazon Region. Mem Inst Oswaldo Cruz 2012; 107:145-154.

6. Coura J, Dias J. Epidemiology, control and surveillance of Chagas disease: 100 years after its discovery. Mem Inst Oswaldo Cruz 2009; 104:31-40.

7. Dias JCP, Macedo VO. Doença de Chagas. In: Coura J, editor. Dinâmica das Doenças Infecciosas e Parasitárias. Rio de Janeiro: Guanabara \& Koogan; 2005. p. 557-593.

8. Silveira A. Os novos desafios e perspectivas futuras do controle. Rev Soc Bras Med Trop 2011; 44:122-124.

9. Ostermayer A, Passos A, Silveira A, Ferreira A, Macedo V, Prata A. O inquérito nacional de soroprevalência de avaliação do controle da doença de Chagas no Brasil (2001-2008). Rev Soc Bras Med Trop 2011; 44:108-121.

10. Secretaria de Vigilancia em Saúde. Ministério da Saúde. Consenso Brasileiro em Doença de Chagas. Rev Soc Bras Med Trop 2005; 38 (supl III): 2-29.

11. Martins-Melo F, Ramos Jr A, Alencar C, Heukelbach J. Prevalence of Chagas disease in Brazil: A systematic review and meta-analysis. Acta Tropica 2014; 130:167-174.

12. Camargo M, Silva G, Castilho E, Silveira A. Inquérito sorológico da prevalência de infecção chagásica no Brasil, 1975/1980. Rev Inst Med Trop S Paulo 1984; 26:192-204.

13. Pan American Health Organization. XVa Reunión de la Comisión Intergubernamental del Cono Sur para la Eliminación de Triatoma infestans y la Interrupción de la Transmisión de Tripanosomiasis Transfusional (INCOSUR-Chagas); 2006.

14. Ministério da Saúde. Secretaria de Vigilância em Saúde. Doença de Chagas: Aspectos epidemiológicos. Brasília: Ministério da Saúde; 2013.

15. Martins-Melo F, Ramos A, Alencar C, Lange W, Heukelbach J. Mortality of Chagas disease in Brazil: spatial patterns and definition of high-risk areas. Trop Med \& Inter Health 2012; 17:1066-1075.

16. Pinto A, Valente S, Valente V, Ferreira Junior A, Coura J. Fase aguda da doença de Chagas na Amazônia brasileira: estudo de 233 casos do Pará, Amapá e Maranhão observados entre 1988 e 2005. Rev Soc Bras Med Trop 2008; 41:602-614.

17. Magalhães B, Coelho L, Maciel M, Ferreira J, Umezawa E, Coura $\mathrm{J}$, et al. Serological survey for Chagas disease in the rural areas of Manaus, Coari, and Tefe in the Western Brazilian Amazon. Rev Soc Bras Med Trop 2011; 44:697-702.

18. Aguilar H, Abad-Franch F, Dias J, Junqueira A, Coura J. Chagas disease in the Amazon Region. Mem Inst Oswaldo Cruz 2007; 102:47-56.
19. Coura JR, Junqueira AC, Fernandes O, Valente SA, Miles MA. Emerging Chagas disease in Amazonian Brazil. Trends Parasitol 2002; 18:171-176.

20. Coura J. Chagas disease: what is known and what is needed - A background article. Mem Inst Oswaldo Cruz 2007; 102:113-122.

21. Valente S, Valente V, Fraiha Neto H. Considerations on the epidemiology and transmission of Chagas disease in the Brazilian amazon. Mem Inst Oswaldo Cruz 1999; 94:395-398.

22. Rojas A, Vinhães M, Rodriguez M, Monroy J, Persaud N, Aznar $\mathrm{C}$, et al. Reunião Internacional sobre Vigilância e Prevenção da Doença de Chagas na Amazônia: implementação da Iniciativa Intergovernamental de Vigilância e Prevenção da doença de Chagas na Amazônia. Rev Soc Bras Med Trop 2005; 38:82-89.

23. Ferraroni JJ, Nunes de Mello JA, Camargo EM. Moléstia de Chagas na Amazônia. Ocorrência de seis casos suspeitos, sorologicamente positivos. Acta Amaz 1977; 7:438-440.

24. França MS, Frade JM, Konasugawa K, Almeida FB. Doença de Chagas - primeiro caso autóctone na Amazônia Ocidental Amazonas - Brasil. Acta Amaz 1980; 10:759-762.

25. Ladeia-Andrade S, Alecrim WD, Fernandes OS, Coura JR, Araújo JR, Ferreira LCL, et al. Doença de Chagas Aguda na Área Urbana de Manaus-AM. Rev Soc Bras Med Trop 2013; 28:121.

26. Coura J, Junqueira A, Boia M, Fernandes O, Bonfante C, Campos $\mathrm{J}$, et al. Chagas disease in the Brazilian Amazon: IV. a new crosssectional study. Rev Inst Med Trop São Paulo 2002; 44:159-165.

27. Viñas-Albajar P, Laredo S, Terrazas M, Coura J. Miocardiopatia dilatada em pacientes com infecão chagásica crônica: relato de dois casos fatais autóctones do Rio Negro, Estado do Amazonas. Rev Soc Bras Med Trop 2003; 36:401-407.

28. Ferreira J, Guerra J, Barbosa M. Ventricular aneurysm in a chronic Chagas disease patient from the Brazilian Amazon region. Rev Soc Bras Med Trop 2009; 42:474-475.

29. Ferreira J, Guerra J, Magalhães B, Coelho L, Maciel M, Barbosa M. Cardiopatia chagásica crônica na Amazônia: uma etiologia a ser lembrada. Arq Bras Cardiol 2009; 93:e107-e109.

30. Barbosa-Ferreira J, Guerra J, Santana Filho F, Magalhães B, Coelho L, Barbosa M. Acometimento cardíaco em Casos de Doença de Chagas Aguda da Amazônia. Arq Bras Cardiol 2010; 94:147-149.

31. Brum-Soares L, Xavier S, Sousa A, Borges-Pereira J, Ferreira J, Costa I, et al. Morbidade da doença de Chagas em pacientes autóctones da microrregião do Rio Negro, Estado do Amazonas. Rev Soc Bras Med Trop 2010; 43:170-177.

32. Borborema M, Guerra JAO, Malheiros R, Fé N, Lacerda MVL, Coelho LIA, et. al. Doença de Chagas urbana em Tefé-AM: Relato de nove casos com suspeita de transmissão oral. Rev Soc Bras Med Trop 2005; 38:491

33. Monteiro W, Magalhães L, Santana Filho F, Borborema M, Silveira H, Barbosa M. Trypanosoma cruzi TcIII/Z3 genotype as agent of an outbreak of Chagas disease in the Brazilian Western Amazonia. Trop Med \& Inter Health 2010; 15:1049-1051.

34. Monteiro W, Magalhães L, Sá A, Gomes M, Toledo M, Borges L, et al. Trypanosoma cruzi IV causing outbreaks of acute Chagas disease and infections by different haplotypes in the Western Brazilian Amazonia. PLoS ONE 2012; 7:e41284.

35. Monteiro W, Teston A, Gruendling A, Reis D, Gomes M, Araújo S, et al. Trypanosoma cruzi I and IV stocks from Brazilian Amazon are divergent in terms of biological and medical properties in mice. PLoS Negl Trop Dis 2013; 7:e2069.

36. Souza-Lima R, Barbosa M, Coura J, Arcanjo A, Nascimento A, Ferreira J, et al. Outbreak of acute Chagas disease associated with oral transmission in the Rio Negro region, Brazilian Amazon. Rev Soc Bras Med Trop 2013; 46:510-514. 
37. Guerra J, Frade J, Barbosa M, Fé N. Doença de Chagas no Estado do Amazonas: $12^{\circ}$ caso autóctone com xenodiagnóstico positivo em ninfas de Triatoma maculata. Rev Soc Bras Med Trop 1999; 32:195.

38. Santana R, Magalhães L, Magalhaes L, Prestes S, Maciel M, Silva $\mathrm{G}$, et al. Trypanosoma cruzi strain TcI is associated with chronic Chagas disease in the Brazilian Amazon. Paras \& Vect 2014; 7:267.

39. Coura J, Vinas P, Brum-Soares L, Sousa A, Xavier S. Morbidity of Chagas heart disease in the microregion of Rio Negro, Amazonian Brazil: a case-control study. Mem Inst Oswaldo Cruz 2013; 108:1009-1013.

40. Coura J, Marquez M, Guerra J, Zauza P, Miguel J, Pereira J. A new survey of the serology of human Trypanosoma cruzi infection in the Rio Negro microregion, Brazilian Amazon: a critical analysis. Mem Inst Oswaldo Cruz 2013; 108:909-913.
41. Zingales B, Andrade S, Briones M, Campbell D, Chiari E, Fernandes $\mathrm{O}$, et al. A new consensus for Trypanosoma cruzi intraspecific nomenclature: second revision meeting recommends TcI to TcVI. Mem Inst Oswaldo Cruz 2009; 104:1051-1054.

42. Zingales B, Miles M, Campbell D, Tibayrenc M, Macedo A, Teixeira M, et al. The revised Trypanosoma cruzi subspecific nomenclature: Rationale, epidemiological relevance and research applications. Inf Gen and Evol 2012; 12:240-253.

43. Monteiro W, Magalhães L, Oliveira J, Guerra J, Silveira H, Ferreira L, et al. Biological behavior of Trypanosoma cruzi stocks obtained from the state of Amazonas, Western Brazilian Amazon, in mice. Rev Soc Bras Med Trop 2012; 45:209-214. 